\title{
Relationship between remote sensing data and field-observed interril erosion
}

\author{
André Geraldo de Lima Moraes(1), Daniel Fonseca de Carvalho(2), \\ Mauro Antonio Homem Antunes ${ }^{(2)}$ and Marcos Bacis Ceddia(1)
}

\begin{abstract}
(1)Universidade Federal Rural do Rio de Janeiro, Instituto de Agronomia, Departamento de Solos, Rodovia BR-465, Km 7, Campus Universitário, CEP 23851-970 Seropédica, RJ, Brazil. E-mail: andrehmuz@hotmail.com, marcosceddia@gmail.com (2)Universidade Federal Rural do Rio de Janeiro, Instituto de Tecnologia, Departamento de Engenharia, Rodovia BR-465, Km 7, Campus Universitário, CEP 23851-970 Seropédica, RJ, Brazil. E-mail: carvalho@ufrrj.br, homemantunes@gmail.com
\end{abstract}

\begin{abstract}
The objective of this work was to evaluate the relationship between different remote sensing data, derived from satellite images, and interrill soil losses obtained in the field by using a portable rainfall simulator. The study was carried out in an area of a hydrographic basin, located in Médio Paraíba do Sul, in the state of Rio de Janeiro - one of the regions most affected by water erosion in Brazil. Evaluations were performed for different vegetation indices (NDVI, Savi, EVI, and EVI2) and fraction images (FI), derived from linear spectral mixture analysis (LSMA), obtained from RapidEye, Sentinel2A, and Landsat 8 OLI images. Vegetation indices are more adequate to predict soil loss than FI, highlighting EVI2, whose exponential model showed $\mathrm{R}^{2}$ of 0.74 . The best prediction models are generated from the RapidEye image, which shows the highest spatial resolution among the sensors evaluated.
\end{abstract}

Index terms: linear spectral mixing analysis, rainfall simulator, vegetation indices.

\section{Relação entre dados de sensoriamento remoto e perdas de solo em entressulcos observadas em campo}

\begin{abstract}
Resumo - O objetivo deste trabalho foi avaliar a relação entre diferentes dados de sensoriamento remoto, derivados de imagens de satélite, e perdas de solo em entressulcos obtidas em campo por meio de um simulador de chuvas portátil. O estudo foi realizado em uma microbacia hidrográfica localizada no Médio Paraíba do Sul, no Estado do Rio de Janeiro - uma das regiões mais afetadas por erosão hídrica no Brasil. Foram avaliados diferentes índices de vegetação (NDVI, Savi, EVI e EVI2) e frações de componentes puros (FCP), derivados de modelos lineares de mistura espectral (MLME), obtidos de imagens RapidEye, Sentinel2A e Landsat 8 OLI. Os índices de vegetação são mais adequados à predição da perda de solo do que as FCP, com destaque para o EVI2, cujo modelo exponencial apresentou $\mathrm{R}^{2}$ de 0,74 . Os melhores modelos de predição são gerados a partir da imagem RapidEye, que apresenta maior resolução espacial entre os sensores avaliados.
\end{abstract}

Termos para indexação: modelos lineares de mistura espectral, simulador de chuva, índices de vegetação.

\section{Introduction}

In agricultural lands of tropical regions, water erosion contributes most to soil degradation, which is facilitated and accelerated by man, through inadequate agricultural management practices and exploitation of natural resources (Mello et al., 2013).

The Paraíba do Sul river basin is one of the Brazilian regions most influenced by water erosion, since more than $20 \%$ of its area (one million hectares) is in high or very high vulnerability to erosion (Machado et al., 2008). The Médio Paraíba do Sul region is considered the most critical one of the entire basin, considering its history of occupation since the coffee cycle in the $19^{\text {th }}$ century, followed by an extensive cattle pasture (Machado et al., 2010).

Temporal and spatial information on soil loss are used as tools to assist soil and water conservation programs, and can be generated by erosion prediction models which commonly use remote sensing techniques to represent the vegetation cover (Renard et al., 1997; De Jong et al., 1999; Hazarika \& Honda, 2001). The vegetation cover has a great influence on the erosive process, as it protects the soil from the rainfall impact, besides influencing the surface roughness and the soil structure, by the contribution of organic carbon, increasing the biological activity, as well as the stability of aggregates, directly affecting the rate 
of water infiltration and, consequently, the runoff and erosion.

Remote sensing data can be used in different ways in erosion prediction models. Many studies are based on the mapping of different soil cover classes, which are related to a degree of susceptibility to erosion and then used, for instance, to estimate the soil cover C factor of the revised universal soil loss equation (Rusle) (Ganasri \& Ramesh, 2016; Gelagay \& Minale, 2016). Furthermore, indices that correlate with vegetation cover are also used such as the normalized difference vegetation index (NDVI) (Rouse et al., 1974) which is the most used in erosion prediction models.

The NDVI has been used for the estimation of Rusle factor C (van der Knijff et al., 1999; Ashiagbor et al., 2013; Durigon et al., 2014; Aiello et al., 2015), and also for other erosion prediction models such as the E30 (Hazarika \& Honda, 2001) and Semmed (soil erosion model for Mediterranean regions) (De Jong et al., 1999). In addition to vegetation indices, the fraction images (FI) generated by linear spectral mixture analysis (LSMA) have been used to obtain the Rusle C factor (Asis \& Omasa, 2007) and to develop erosion indices (Asis et al., 2008).

Despite the wide use of these tools, remote sensing data have not been correlated with soil losses measured in situ.

The objective of this work was to evaluate the relationship between different remote sensing data, derived from satellite images, and interrill soil losses obtained in the field by using a portable rainfall simulator.

\section{Materials and Methods}

The study was carried out in the Médio Paraíba do

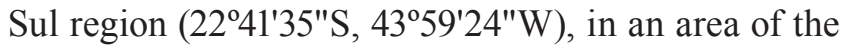
hydrographic basin of Cachimbal stream, inside the Instituto Federal de Educação e Tecnologia do Rio de Janeiro, Nilo Peçanha Campus (IFRJ), located in the municipality of Pinheiral, Rio de Janeiro, Brazil (Figure 1). The climate of the region, according to the Köppen-Geiger's classification, is Cwa - tropical climate of dry winter and rainy summer, with average maximum and minimum temperatures of 30.9 and $16.8^{\circ} \mathrm{C}$, respectively. The annual precipitation varies between 1,300 and $1,500 \mathrm{~mm}$, with water surplus of
100 to $150 \mathrm{~mm}$ monthly from December to March, and water deficiency from July to September.

The region is at an altitude ranging from $360 \mathrm{~m}$ to $720 \mathrm{~m}$, and shows several forms of relief with different degrees of dissection, predominating slopes with varied gradients $(72.0 \%)$, few areas of flattened tops (5.7\%), and narrow floodplains $(22.3 \%)$ in the basin's structural valleys near the banks of its main channel (Oliveira, 1998).

This region is inserted in an area of ecological domain of the Atlantic Forest, where the original vegetation is a Submontane Semidecidual Seasonal Forest, which is typical of altitude zones between 300 and $800 \mathrm{~m}$. The vegetation is currently dominated by unmanaged, planted, and spontaneous pastures, which occur at different degradation stages, level of use, or abandonment, and forests at different successional stages.

The commonly encountered soil classes, according to SiBCS (Santos et al., 2013) and World... (2015) are the Argissolos (Acrisols), Cambissolos (Cambisols) in the hills and slopes, Cambissolos Flúvicos and Neossolos Flúvicos (Fluvisols) in the lowland areas near the Cachimbal and Paraíba do Sul rivers, and the Gleissolos Háplicos (Gleysols), in the poorly drained areas.

The interrill soil loss was quantified from July to September 2015 through a portable rainfall simulator (Alves Sobrinho et al., 2008), which operates with two parallel Veejet 80.150 nozzles, positioned at $2.30 \mathrm{~m}$ above the soil surface, and has an experimental useful area (plot) of $0.70 \mathrm{~m}^{2}$. The plots were delimited by a rectangular shaped gutter, built in galvanized steel sheets that allowed the collection of the drained water volume (runoff). According to these authors, rainfall simulations on areas smaller than $1.5 \mathrm{~m}^{2}$ have been used to study surface sealing, interrill, and splash erosion, but cannot be used for studying processes that require larger areas as is the case with rill erosion.

The tests with rain simulation were performed in 71 points in the study area (Figure 1), which were selected using the ACDC function (association/ correlation measures, and the marginal distribution of covariates), using the package Spassan (SamuelRosa, 2016) on R software, adopting the following as covariables: NDVI of a RapidEye image of 06/06/2014; a slope map derived from a digital elevation model (DEM) of $5 \mathrm{~m}$ of spatial resolution; and a map of 

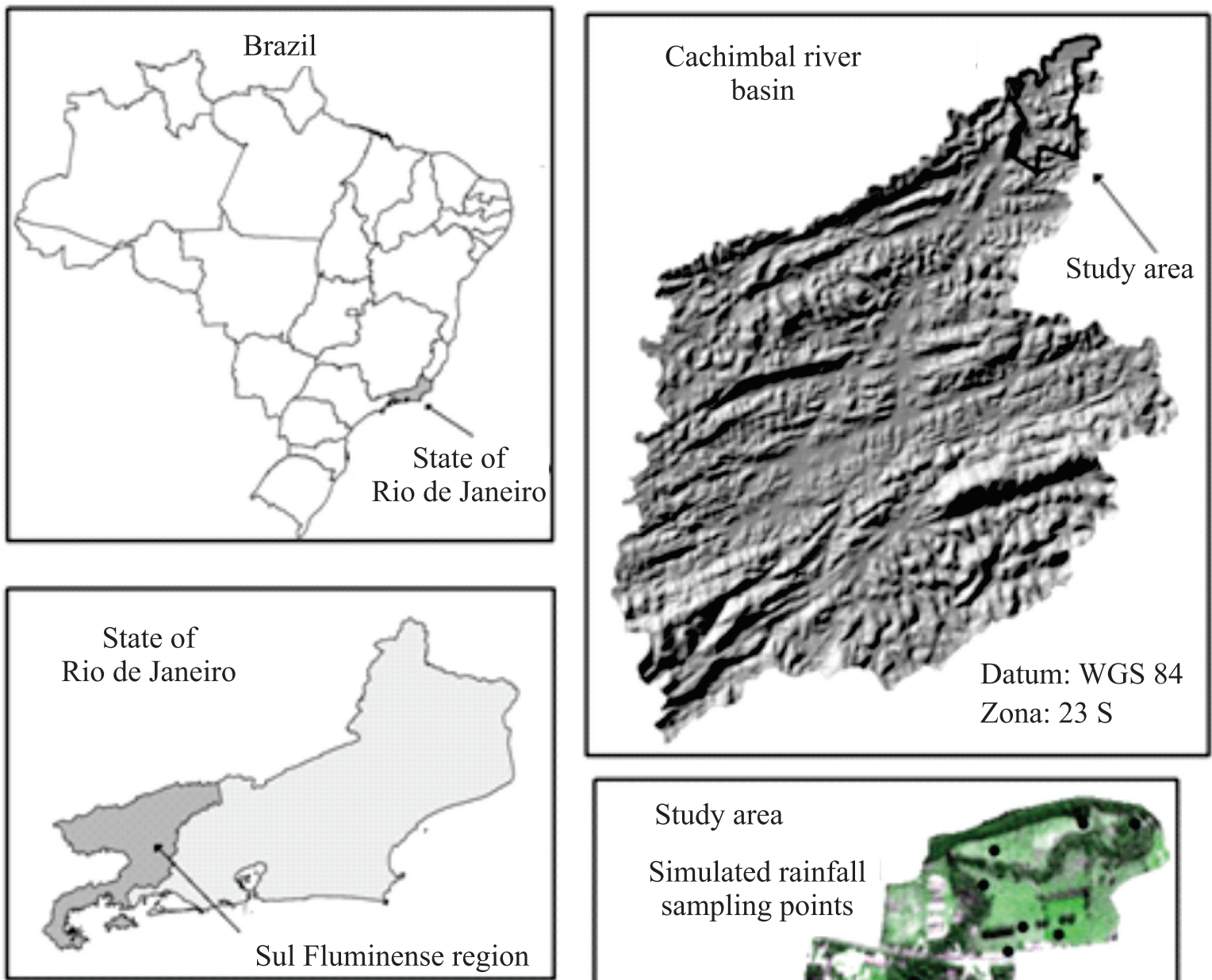

Datum: WGS 84
Zona: $23 \mathrm{~S}$
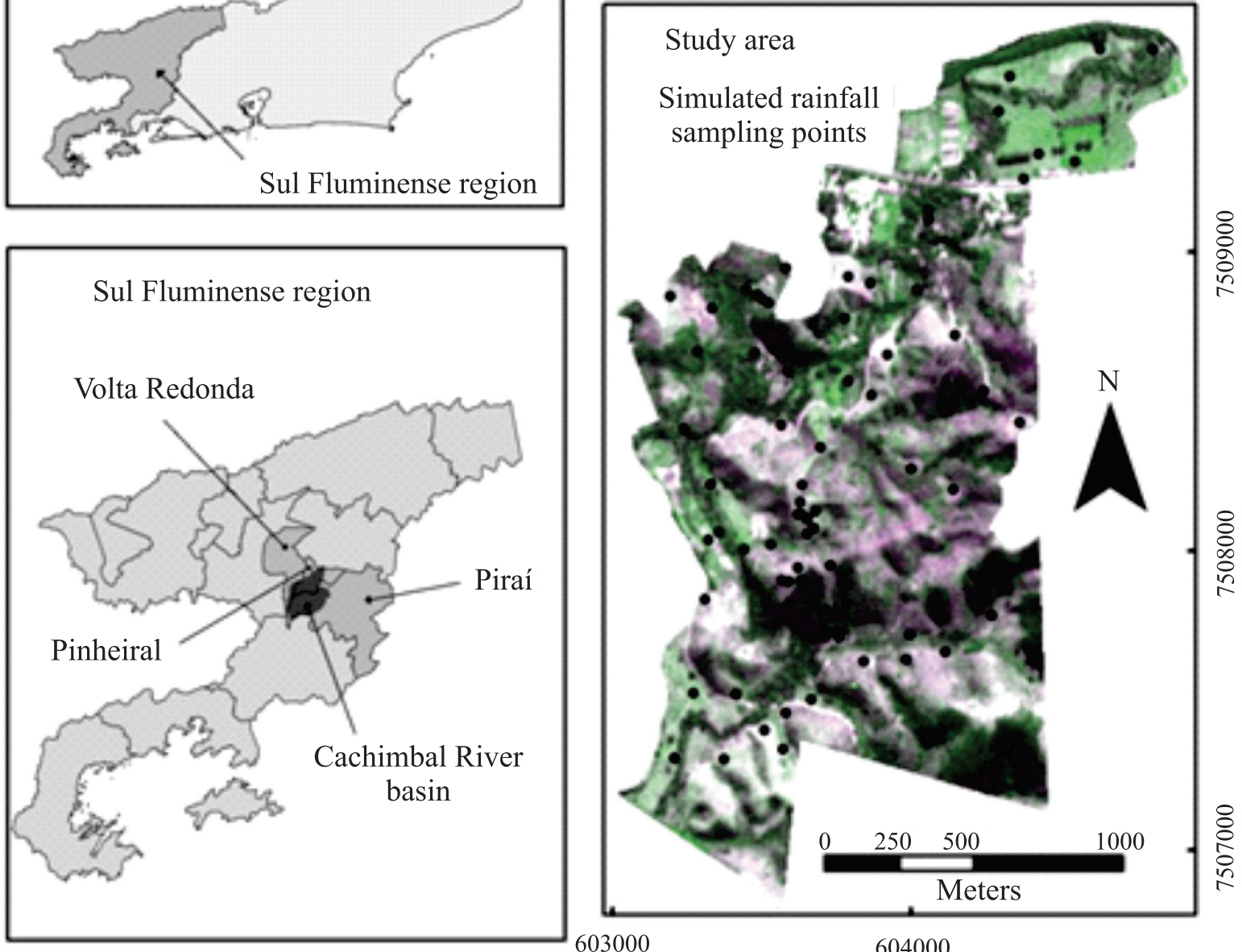

Figure 1. Study area and simulated rainfall sampling points, in the Cachimbal River basin, in the state of Rio de Janeiro, Brazil. 
soil classes of 1:10,000 scale. The choice of points was performed with the purpose of representing the variability of attributes (covariables) that influence the interril soil loss (vegetation cover, relief, and soil classes). Part of the micro basin area out of the IFRJ campus could not be used. Therefore, 41 tests were carried out at points outlined by the ACDC, and the other points were delineated through the expertise of the researcher's team.

After the definition of the points, rainfall intensity at $60 \mathrm{~mm}$ per hour was applied for one hour, counted from the beginning of the runoff. Twenty-four hours before each test, and with the objective to show more favorable conditions to the occurrence of surface runoff, the plots received a pre-wetting, unifying the humidity conditions before the simulated rainfall application (Almeida et al., 2016). This procedure was performed by adding water gently and homogeneously in the plot, through a watering can, until the occurrence of runoff.

The interrill soil loss was quantified by the difference between the water depth applied by the simulator and the drained water depth, collected during 1 min for every 5 min of testing. The drained material was taken to the drying oven and, after drying, the soil mass per minute was obtained, and soil loss for the entire one hour rain was calculated.

Remote sensing data were derived from RapidEye, Sentinel 2A, and Landsat 8 OLI images, in dates near the period of execution of field tests (Table 1). The images were subjected to atmospheric correction and were transformed to surface reflectance using the 6S (second-simulation of satellite signal in the solar spectrum) model for RapidEye (Antunes et al., 2014) and Landsat 8 OLI images (Bonansea et al., 2015), and sen2cor software implemented in the Sentinel

Table 1. Characteristics of tested satellite images.

\begin{tabular}{lcccc}
\hline Image & Data & $\begin{array}{c}\text { Number } \\
\text { of bands }\end{array}$ & $\begin{array}{c}\text { Spatial resolution } \\
(\mathrm{m})\end{array}$ & License \\
\hline RapidEye & $07 / 12 / 2015$ & 5 & 6.5 resampled for 5 & Private $^{(2)}$ \\
Sentinel 2A & $08 / 01 / 2015$ & 13 & 10 & Free \\
Landsat 8 OLI & $07 / 14 / 2015$ & 13 & 30 & Free \\
\hline
\end{tabular}

${ }^{(1)}$ Spatial resolution of the bands of interest used for vegetation monitoring. ${ }^{(2)}$ RapidEye images until 2014 can be obtained for free, for research purposes, through the Ministério do Meio Ambiente (MMA) of Brazil. application platform (SNAP) (Müller-Wilm, 2016) for the Sentinel 2A image.

The vegetation indices derived from each image, such as the NDVI, the soil-adjusted vegetation index (Savi) (Huete, 1998), the enhanced vegetation index (EVI) (Huete et al., 1997), and the EVI 2 (Jiang et al., 2008), which are below described:

$$
\begin{gathered}
\mathrm{NDVI}=\rho_{\mathrm{NIR}}-\rho_{\mathrm{RED}} / \rho_{\mathrm{NIR}}+\rho_{\mathrm{RED}} \\
\text { Savi }=(1+\mathrm{L})\left(\rho_{\mathrm{NIR}}-\rho_{\mathrm{RED}}\right) / \rho_{\mathrm{NIR}}+\rho_{\mathrm{RED}}+\mathrm{L} \\
\mathrm{EVI}=2.5\left(\rho_{\mathrm{NIR}}-\rho_{\mathrm{RED}} / \rho_{\mathrm{NIR}}-\mathrm{C}_{1} \rho_{\mathrm{RED}}+\mathrm{C}_{2} \rho_{\mathrm{BLUE}}+\mathrm{L}\right) \\
\mathrm{EVI}=2.5\left(\rho_{\mathrm{NIR}}-\rho_{\mathrm{RED}} / \rho_{\mathrm{NIR}}+2.4 \rho_{\mathrm{RED}}+1\right)
\end{gathered}
$$

in which: $\rho_{\mathrm{NIR}}$ is the near-infrared reflectance; $\rho_{\mathrm{RED}}$ is the red reflectance; $\rho_{\text {BLUE }}$ is the blue reflectance; $L$ is the soil adjustment factor, which is 0.5 for Savi and 7.5 for EVI; $\mathrm{C}_{1}=1.0$; and $\mathrm{C}_{2}=6.0$.

Fraction images (FI) were crated through linear spectral mixture analysis (LSMA). The LSMA is an alternative to determine the fractions of the components within an impure (mixed) pixel. An important assumption of the LSMA is that the spectral signature of a given pixel is the weighted proportional linear combination of the "end member" spectra (Shimabukuro \& Smith, 1991). Mathematically, the LSMA model is expressed as:

$$
R i=\sum_{j=1}^{N} f_{j} r_{i j}+\varepsilon_{i} \text { and } \sum_{j=1}^{N} f_{j}=1 ; 0 \leq f_{j} \leq 1,
$$

in which: $i$ is the number of spectral bands used; $j=1$, ..., $\mathrm{N}$ is the number of "end members"; ri is the spectral reflectance of the mixed pixel in band $i ; f_{j}$ is the fraction of the pixel area covered by the "end member" $\mathrm{j}$; $\mathrm{r}_{\mathrm{ij}}$ represents the reflectance of the "end member" $\mathrm{j}$ in the band $\mathrm{i}$; and $\varepsilon \mathrm{i}$ is the residual error in band $\mathrm{i}$. Besides, two constraints on the solution of values $f j$ are maintained: the fractions in all the FI add up to one; and each FI must range between 0 and 1. The input to the model is given by the spectral reflectance (Ri) and the "end member" spectra (rij). A single solution is possible, since the number of "end members" is equal to the number of spectral bands plus one. The residual error is the difference between the measured and modeled spectrum in each band. Residues in all bands 
for each pixel in the image can be calculated to give a root mean square error (RMSE), which is useful in assessing the validity of selected "end members".

"End members" of abundant vegetation, bare soil, and shade were used; the first two ones were selected because they represent factors that interfere in the erosive process (Asis \& Omasa, 2007), and the third one because it represents a common feature in the study area. This procedure resulted in the definition of the three FI related to vegetation $\left(\mathrm{FI}_{\mathrm{veg}}\right)$, bare soil $\left(\mathrm{FI}_{\mathrm{bs}}\right)$, and shade $\left(\mathrm{FI}_{\mathrm{sh}}\right)$.

The models were created in a free version of the software CurveExpert 1.4 (Hyams, 2010), and the comparison between the different remote sensing data and also between different sensors were done through the coefficients of determination $\mathrm{R}^{2}$ and RMSE obtained between SL and remote sensing data.

\section{Results and Discussion}

The average SL obtained in the study area was $74.4 \mathrm{~kg} \mathrm{ha}{ }^{-1}$, with values varying from 0.00 to $618.0 \mathrm{~kg} \mathrm{ha}^{-1}$ (Table 2). The mean soil loss values and the number of simulated rainfall tests for the different types of cover are also presented.

The highest average SLs were found in the degraded pasture class $\left(267.0 \mathrm{~kg} \mathrm{ha}^{-1}\right)$, followed by the classes: pasture (66.7 $\left.\mathrm{kg} \mathrm{ha}^{-1}\right)$, fallow area $\left(47.4 \mathrm{~kg} \mathrm{ha}^{-1}\right)$, unmanaged pasture $\left(34.8 \mathrm{~kg} \mathrm{ha} \mathrm{ha}^{-1}\right)$, and forest $\left(15.2 \mathrm{~kg} \mathrm{ha}^{-1}\right)$ (Table 2). Studies with natural rainfall have shown similar results where the largest SL occurs in degraded pastures and exposed soil areas, while smaller SLs are found in natural systems (native forests) (Martins et al., 2003; Pires et al., 2006).

Degraded pastures are in an advanced stage of degradation, showing at least erosion in furrows and

Table 2. Average, minimum, and maximum soil losses, and number of tests per soil cover class.

\begin{tabular}{lcccc}
\hline Soil cover class & \multicolumn{3}{c}{ Soil loss $\left(\mathrm{kg} \mathrm{ha}^{-1}\right)$} & $\begin{array}{c}\text { Tests per soil } \\
\text { cover class }\end{array}$ \\
\cline { 2 - 4 } & Average & Maximum & Minimum & 13 \\
\hline Forest & 15.2 & 41.2 & 0.0 & 12 \\
Unmanaged pasture & 34.8 & 97.8 & 0.0 & 11 \\
Fallow area & 47.4 & 102.0 & 0.0 & 26 \\
Pasture & 66.7 & 158.8 & 20.88 & 9 \\
Degraded pasture & 267.0 & 618.0 & 99.5 & 71 \\
\hline Total & 74.4 & 618.0 & 0.00 & \\
\hline
\end{tabular}

burned areas (without vegetation cover). These soils, deprived of vegetal protection and compacted by cattle trampling, are easily impacted by the rain drops, which increases the detachment of particles and the sealing of the soil surface, reduces water infiltration capacity, and increases surface runoff, resulting in larger SLs. The pasture areas showed SL average four times as low as that of the degraded pastures. These areas have relatively homogeneous vegetation cover, but are commonly considered areas from moderate to strong laminar erosion. According to Rocha Junior et al. (2017), conventional and burned pasture managements, usually adopted in the Atlantic rainforest biome, causes high losses of sediment, organic carbon, and nutrients, in comparison to fertilized and well managed pasture systems.

Fallow areas, which showed the third largest soil loss $\left(47.4 \mathrm{~kg} \mathrm{ha}^{-1}\right)$, were isolated in order to be reforested, but without the implantation of forest species. They are typically covered by Panicum maximum grass and frequently suffer from burnings during the dry seasons of the year, which does not allow of the natural regeneration of forests, and favors the continuity of the soil degradation process.

The unmanaged pasture areas showed the second lowest soil loss $\left(34.8 \mathrm{~kg} \mathrm{ha}^{-1}\right)$. They are composed of plant species of low interest for cattle, promoting less trampling, also showing the development of varied vegetal species with different sizes and growth habits that consequently protect the soil even more.

Although the tests with simulated rainfall were performed under the canopy, the forest areas showed the lowest SL average (15.2 $\left.\mathrm{kg} \mathrm{ha}^{-1}\right)$ among the coverages. This effect caused by the vegetation cover and, in this case, mainly by the litter in the reduction of water erosion in natural systems (forests) is related to its capacity to minimize the impact of the rain drops, and to soften the runoff, besides positively influencing the soil structure through the input of organic matter and biological activity (Martins et al., 2003; Pires et al., 2006).

The SL values show great variation within each soil cover class, and can be explained by the variability of other attributes that may influence the erosive process, such as slope (Wang et al., 2017) and soil erodibility, which is based on properties of the soil, such as texture and structure, among others (Vaezi et al., 2016). 
The mean, minimum, and maximum values of vegetation indices, and fraction images (FI) derived from RapidEye image for the different coverages are presented (Table 3). In general, the highest values of NDVI, Savi, EVI, EVI2, and $\mathrm{FI}_{\mathrm{veg}}$ are found in forests, and the lowest ones in the degraded pastures. The opposite is found for $\mathrm{FI}_{\mathrm{bs}}$. These results are consistent, as higher values of vegetation index and $\mathrm{FI}_{\text {veg }}$ are related to a denser vegetation cover (Rouse et al., 1974; Huete et al., 1997; Jiang et al., 2008), while high-FI values are related to exposed soils (Asis \& Omasa, 2007). The results show a great difference between the data values for forest and degraded pastures, but show similar values for unmanaged pasture, fallow, and pasture.

The models generated with vegetation indices derived from the RapidEye image showed the best fit with SL. The model derived from EVI2 showed the highest $\mathrm{R}^{2}$ (0.74) and lower RMSE (54.15 $\mathrm{kg} \mathrm{ha}^{-1}$ ),

Table 3. Average, minimum, and maximum values of remote sensing data derived from RapidEye image of the main soil cover classes in the study area.

\begin{tabular}{|c|c|c|c|c|c|c|}
\hline \multirow[t]{2}{*}{ Data } & \multirow[t]{2}{*}{ Statistic } & \multicolumn{5}{|c|}{ Soil cover classes } \\
\hline & & Forest & UMP & FA & Pasture & DP \\
\hline \multirow{3}{*}{ NDVI } & Average & 0.84 & 0.75 & 0.69 & 0.69 & 0.49 \\
\hline & Maximum & 0.90 & 0.85 & 0.84 & 0.85 & 0.63 \\
\hline & Minimum & 0.80 & 0.62 & 0.61 & 0.44 & 0.33 \\
\hline \multirow{3}{*}{ Savi } & Average & 0.43 & 0.39 & 0.39 & 0.38 & 0.28 \\
\hline & Maximum & 0.52 & 0.47 & 0.56 & 0.61 & 0.38 \\
\hline & Minimum & 0.35 & 0.31 & 0.30 & 0.29 & 0.20 \\
\hline \multirow{3}{*}{ EVI } & Average & 0.41 & 0.36 & 0.36 & 0.35 & 0.25 \\
\hline & Maximum & 0.52 & 0.45 & 0.57 & 0.55 & 0.35 \\
\hline & Minimum & 0.32 & 0.28 & 0.28 & 0.24 & 0.17 \\
\hline \multirow{3}{*}{ EVI 2} & Average & 0.42 & 0.38 & 0.38 & 0.37 & 0.27 \\
\hline & Maximum & 0.51 & 0.48 & 0.59 & 0.51 & 0.37 \\
\hline & Minimum & 0.35 & 0.30 & 0.29 & 0.27 & 0.19 \\
\hline \multirow{3}{*}{$\mathrm{FI}_{\mathrm{sh}}$} & Average & 0.47 & 0.47 & 0.33 & 0.43 & 0.43 \\
\hline & Maximum & 0.65 & 0.65 & 0.60 & 0.58 & 0.56 \\
\hline & Minimum & 0.29 & 0.17 & 0.10 & 0.06 & 0.26 \\
\hline \multirow{3}{*}{$\mathrm{FI}_{\mathrm{veg}}$} & Average & 0.52 & 0.46 & 0.49 & 0.45 & 0.30 \\
\hline & Maximum & 0.71 & 0.60 & 0.87 & 0.85 & 0.47 \\
\hline & Minimum & 0.38 & 0.32 & 0.31 & 0.27 & 0.16 \\
\hline \multirow{3}{*}{$\mathrm{FI}_{\mathrm{bs}}$} & Average & 0.02 & 0.07 & 0.16 & 0.17 & 0.26 \\
\hline & Maximum & 0.06 & 0.19 & 0.26 & 0.32 & 0.39 \\
\hline & Minimum & 0.00 & 0.02 & 0.01 & 0.07 & 0.14 \\
\hline
\end{tabular}

UMP, unmanaged pasture; FA, fallow area; DP, degraded pasture. followed by the respective $\mathrm{R}^{2}$ and RMSE values of EVI $\left(0.72,56.37 \mathrm{~kg} \mathrm{ha}^{-1}\right)$, Savi $\left(0.70,57.63 \mathrm{~kg} \mathrm{ha}^{-1}\right)$, and NDVI $\left(0.66,62.41 \mathrm{~kg} \mathrm{ha}^{-1}\right)$ (Table 4 and Figure 2). Savi, EVI, and EVI2 are modifications of the NDVI. Savi has a soil correction factor. However, EVI has the soil correction factor and adopts the blue band for the correction of the red band for atmospheric scattering by aerosols, and, despite being a modification of EVI, EVI2 does not use the blue band. Improved vegetation indices (EVI and EVI2) show better responses to vegetation (Huete et al., 1997; Jiang et al., 2008) and, therefore, a greater correlation potential with soil loss. Among the FIs, the $\mathrm{FI}_{\text {veg }}$ showed a better fit with the SL, with $\mathrm{R}^{2}$ of 0.64 and RMSE of $54.15 \mathrm{~kg} \mathrm{ha}^{-1}$, followed by the bare soil fraction image $\left(\mathrm{FI}_{\mathrm{bs}}\right)$. When testing FIs and NDVI for Rusle factor C prediction, Asis \& Omasa (2007) found better adjustments for $\mathrm{FI}_{\mathrm{veg}}$ and $\mathrm{FI}_{\mathrm{bs}}$, in

Table 4. Soil loss prediction models based on vegetation indices and fraction images derived from RapidEye, Sentinel 2A, and Landsat 8 OLI images.

\begin{tabular}{|c|c|c|c|}
\hline $\begin{array}{l}\text { Remote sensing } \\
\text { data }\end{array}$ & Model & $\mathrm{R}^{2}$ & $\begin{array}{c}\text { RMSE } \\
\left(\mathrm{kg} \mathrm{ha}^{-1}\right)\end{array}$ \\
\hline \multicolumn{4}{|c|}{ RapidEye } \\
\hline NDVI & $\mathrm{SL}=14.473 \mathrm{NDVI}^{-3.335}$ & 0.66 & 62.41 \\
\hline Savi & $\mathrm{SL}=0.762 \mathrm{Savi}^{-4.201}$ & 0.70 & 57.63 \\
\hline EVI & $\mathrm{SL}=0.869 \mathrm{EVI}^{-3.739}$ & 0.72 & 56.37 \\
\hline EVI 2 & $\mathrm{SL}=0.590 \mathrm{EVI} 2^{-4.229}$ & 0.74 & 54.15 \\
\hline $\mathrm{FI}_{\mathrm{sh}}$ & $\mathrm{SL}=99.675 \mathrm{FI}_{\mathrm{sh}}{ }^{0.309}$ & 0.01 & 105.16 \\
\hline $\mathrm{FI}_{\mathrm{veg}}$ & $\mathrm{SL}=6.527 \mathrm{FI}_{\mathrm{veg}}-2.503$ & 0.64 & 62.72 \\
\hline $\mathrm{FI}_{\mathrm{bs}}$ & $\mathrm{SL}=1192.513 \mathrm{FI}_{\mathrm{bs}}{ }^{1.468}$ & 0.41 & 82.16 \\
\hline \multicolumn{4}{|c|}{ Sentinel 2A } \\
\hline NDVI & $\mathrm{SL}=177.473-182.573 \mathrm{NDVI}$ & 0.07 & 102.17 \\
\hline Savi & $\mathrm{SL}=-8.280-69.708 \ln S a v i$ & 0.03 & 104.07 \\
\hline EVI & $\mathrm{SL}=7.580-55.441 \ln \mathrm{EVI}$ & 0.03 & 104.41 \\
\hline EVI2 & $\mathrm{SL}=-65.944-6.595 \ln E V I 2$ & 0.03 & 103.94 \\
\hline $\mathrm{FI}_{\mathrm{sh}}$ & $\mathrm{SL}=93.185-45.270 \mathrm{FI}_{\mathrm{sh}}$ & 0.00 & 105.58 \\
\hline $\mathrm{FI}_{\text {veg }}$ & $\mathrm{SL}=28.262-48.419 \mathrm{FI}_{\mathrm{veg}}$ & 0.03 & 104.31 \\
\hline $\mathrm{FI}_{\mathrm{bs}}$ & $\mathrm{SL}=37.251-209.527 \mathrm{FI}_{\mathrm{bs}}$ & 0.05 & 102.87 \\
\hline \multicolumn{4}{|c|}{ Landsat8 OLI } \\
\hline NDVI & $\mathrm{SL}=211.447-163.303 \mathrm{NDVI}$ & 0.03 & 103.94 \\
\hline Savi & $\mathrm{SL}=67.597+17.897 \mathrm{Savi}$ & 0.00 & 105.75 \\
\hline EVI & $\mathrm{SL}=73.110+3.510 \mathrm{EVI}$ & 0.00 & 105.76 \\
\hline EVI2 & $\mathrm{SL}=72.1771+6.115 \mathrm{EVI} 2$ & 0.00 & 105.76 \\
\hline $\mathrm{FI}_{\mathrm{sh}}$ & $\mathrm{SL}=98.271-68.557 \mathrm{FI}_{\mathrm{sh}}$ & 0.01 & 105.19 \\
\hline $\mathrm{FI}_{\mathrm{veg}}$ & $\mathrm{SL}=75.959-2.687 \mathrm{FI}_{\mathrm{veg}}$ & 0.00 & 105.76 \\
\hline $\mathrm{FI}_{\mathrm{bs}}$ & $\mathrm{SL}=133.355 \mathrm{FI}_{\mathrm{bs}}{ }^{-19.711}$ & 0.04 & 103.72 \\
\hline
\end{tabular}

RMSE, root mean square error.

Pesq. agropec. bras., Brasília, v.53, n.3, p.332-341, Mar. 2018 DOI: 10.1590/S0100-204X2018000300008 
comparison to NDVI. However, their work sought to correlate remote sensing data to Rusle $\mathrm{C}$ factor, and not to SL directly. As expected, the shadow fraction $\left(\mathrm{FI}_{\mathrm{sh}}\right)$ had the lowest correlation with the SL $\left(\mathrm{R}^{2}=0.01\right)$ due to the fact that the shade variable does not have any interference in the erosive process.

The low performance of the fraction images can be attributed to the mountainous relief of the region, which generates many shaded areas that mask the most interesting targets, such as bare soil and abundant vegetation. Attempts were made to use other combinations of "end members", which does not provide satisfactory results, since the RMSEs were high, as well as the number of pixels with values below 0 and above 1 in the FIs.

The mean RMSE of the LSMA-FIs was 0.003, and the number of pixels with values below 0 and above 1 in the FCP was $0.1 \%$, indicating that the choice of "end members" was correct (Shimabukuro \& Smith, 1991). It is expected that this method presents better results in less mountainous relief areas, where there is less shadow effect generated by the relief.

For all variables derived from the RapidEye image, exponential models were fitted (Table 4 and Figure 2), which seem to represent more adequately the relationships of soil loss with remote sensing data. According to van der Knijff et al. (1999), exponential models are more adequate than linear ones for the estimation of Rusle $\mathrm{C}$ factor from NDVI, but they point out that, at that time, there were no field data to support their assertion. The results of this work corroborate the assertion of van der Knijff et al. (1999), and are in opposition to Aiello et al. (2015), Durigon et al. (2014), Ashiagbor et al. (2013) and De Jong et al. (1999), who used linear regressions to represent the relationships between vegetation indices and soil loss.
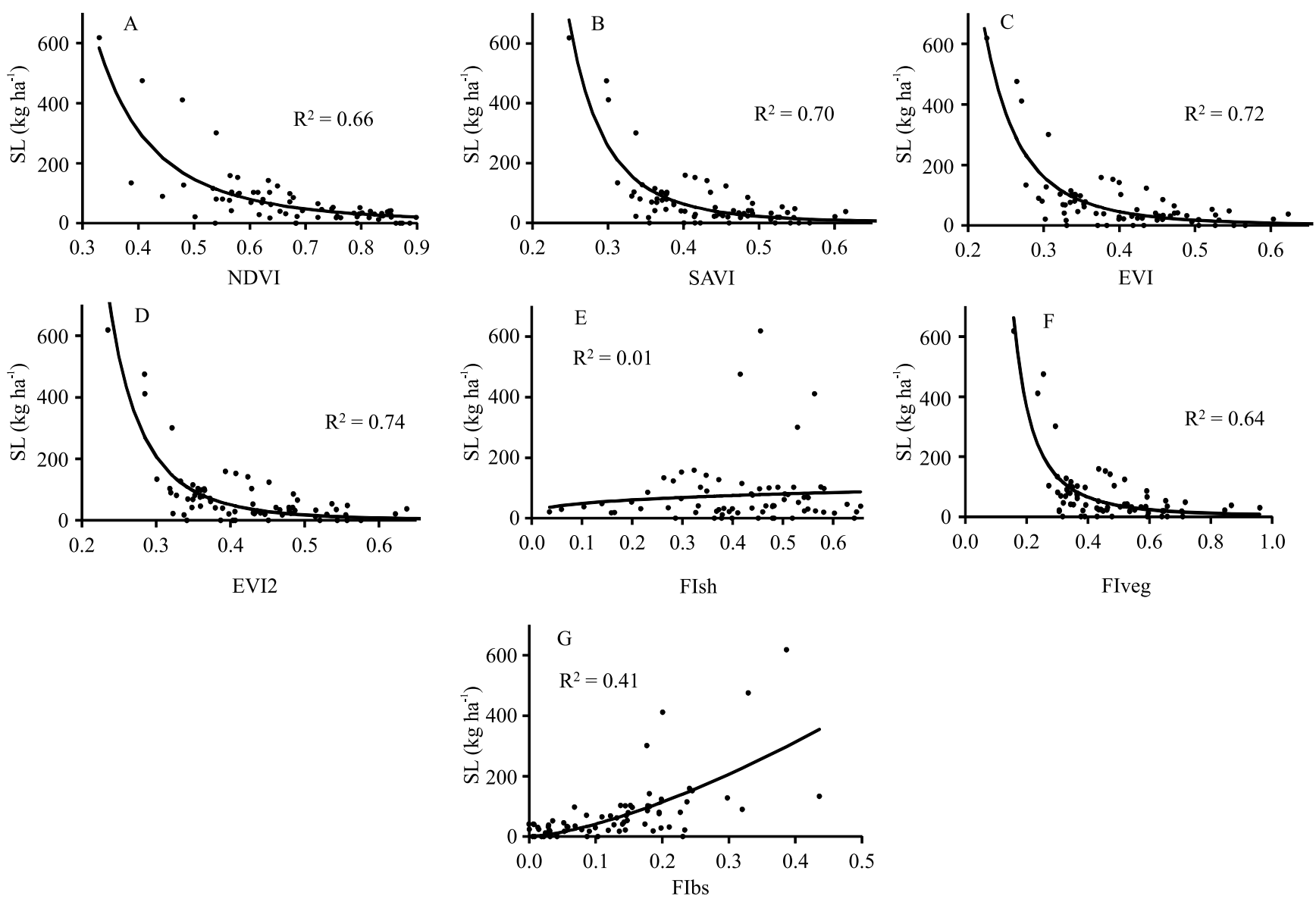

Figure 2. Correlation between soil loss and NDVI (A), Savi (B), EVI (C), EVI2 (D), FI $I_{\text {sh }}(\mathrm{E}), \mathrm{FI}_{\mathrm{veg}}(\mathrm{F})$, and FI $\mathrm{bs}_{\mathrm{bs}}(\mathrm{G}), \mathrm{derived}$ from RapidEye image. 
The relationship between NDVI derived from RapidEye image and SL for the different classes of coverage can be observed in Figure 3. Soil loss measured under forest is associated with high-NDVI values, while an opposite effect is observed in areas

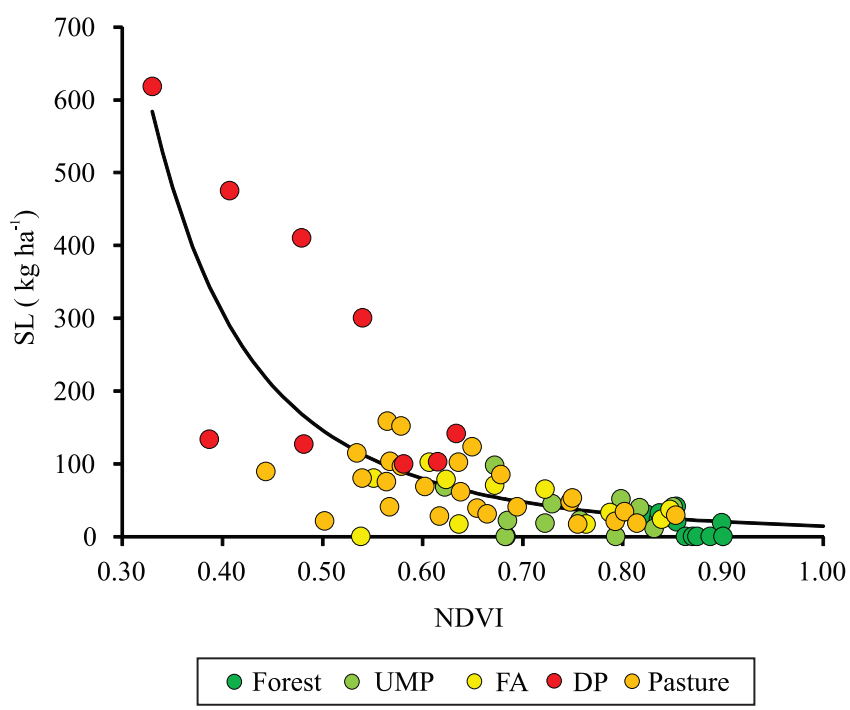

Figure 3. Correlation between NDVI derived from RapidEye image and soil loss (SL), for the different soil cover classes: UMP, unmanaged pasture; FA, fallow area; DP, degraded pasture. of degraded pastures. The variation of soil loss occurs gradually from the forest class to unmanaged pasture, fallow, and pasture, and, more abruptly, to the degraded pasture class, characterizing the exponential form of the response between SL and NDVI (van der Knijff et al., 1999).

In general, the best results were obtained from the RapidEye image, while the adjustments obtained through data derived from the Sentinel 2A image were very low and practically null when using data derived from Landsat 8 OLI (Table 4). With the decreasing of spatial resolution, adjustments of all tested data became worse due to the heterogeneity of the soil cover of the region, influenced by fragments of different types of soil cover of relatively small sizes. In resolution images of $30 \mathrm{~m}$ (Landsat $8 \mathrm{OLI}$ ) and $10 \mathrm{~m}$ (Sentinel 2A), several soil cover fragments may be present in the same pixel, resulting in a mixture of the reflectance values of the pixel. Thus, the use of spatial resolution images of $10 \mathrm{~m}$ (Sentinel 2A) and $30 \mathrm{~m}$ (Landsat 8 OLI) were inadequate for the present study where the simulated rainfall was applied in a $0.70 \mathrm{~m}^{2}$ plot. The difference between the same data (EVI2), derived for the different images, shows the larger (RapidEye) and lower (Landsat 8 OLI) levels of detail offered by each image (Figure 4).
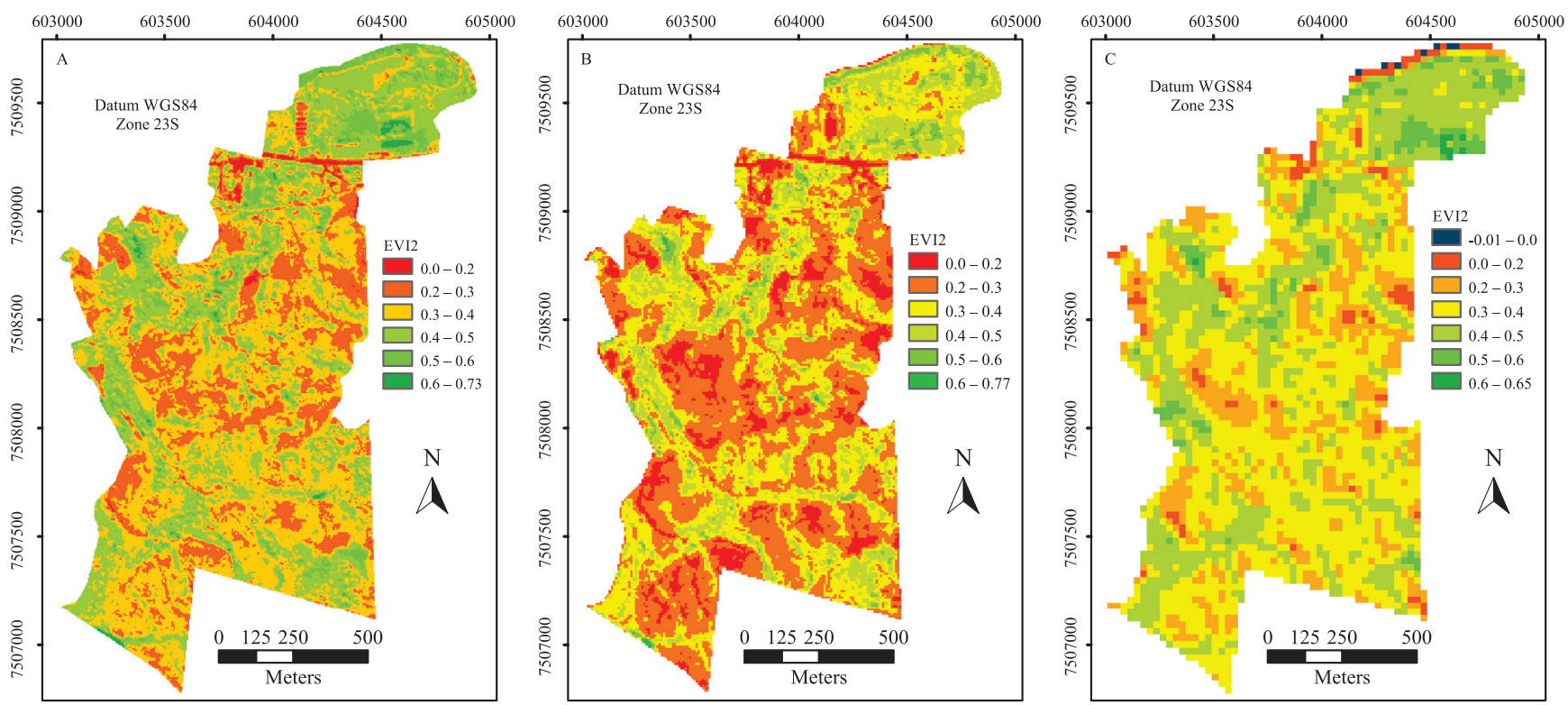

Figure 4. EVI2 derived from three different images: RapidEye (A), Sentinel 2A (B), and Landsat 8 OLI (C) of the Cachimbal River basin, in the state of Rio de Janeiro, Brazil. 


\section{Conclusions}

1. The vegetation indices present better responses to soil loss, in comparison to the FIs, especially EVI2.

2. The adjustments of the models indicate that the exponential form is the most adequate to represent the relationships between remote sensing data and soil losses.

3. The best adjustments with soil loss are obtained from data derived from RapidEye images, which show the highest spatial resolution among the sensors evaluated.

\section{Acknowledgments}

To Coordenação de Aperfeiçoamento de Pessoal de Nível Superior (Capes), for scholarship granted; to Universidade Federal Rural do Rio de Janeiro (UFRRJ) and to Instituto Federal de Educação e Tecnologia do Rio de Janeiro (IFRJ), Campus Nilo Peçanha, for the permission to use their infrastructure; to Agência da Bacia Hidrográfica do Rio Paraíba do Sul (Agevap) - and Comitê Médio Paraíba do Sul -, for financial support; to Ministério do Meio Ambiente (MMA), for the access to RapidEye image of 2014; and to Santiago $\&$ Cintra GeoTecnologias, for enabling the acquisition of RapidEye image of 2015.

\section{References}

AIELLO, A.; ADAMO, M.; CANORA, F. Remote sensing and GIS to assess soil erosion with RUSLE3D and USPED at river basin scale in Southern Italy. Catena, v.131, p.174-185, 2015. DOI: 10.1016/j.catena.2015.04.003.

ALMEIDA, W.S. de; CARVALHO, D.F. de; PANACHUKI, E.; VALIM, W.C.; RODRIGUES, S.A.; VARELLA, C.A.A. Erosão hídrica em diferentes sistemas de cultivo e níveis de cobertura do solo. Pesquisa Agropecuária Brasileira, v.51, p.1110-1119, 2016. DOI: $10.1590 / \mathrm{s} 0100-204 \times 2016000900010$.

ALVES SOBRINHO, T.; GÓMEZ-MACPHERSON, H.; GÓMEZ, J.A. A portable integrated rainfall and overland flow simulator. Soil Use and Management, v.24, p.163-170, 2008.

ANTUNES, M.A.H.; DEBIASI, P.; SIQUEIRA, J.C. dos S. Avaliação espectral e geométrica das imagens RapidEye e seu potencial para o mapeamento e monitoramento agrícola e ambiental. Revista Brasileira de Cartografia, v.66, p.105-113, 2014.

ASHIAGBOR, G.; FORKUO, E. K.; LAARI, P.; AABEYIR, R. Modeling soil erosion using RUSLE and GIS tools. International Journal of Remote Sensing and Geoscience, v.2, p.7-17, 2013.
ASIS, A.M. de; OMASA, K. Estimation of vegetation parameter for modeling soil erosion using linear spectral mixture analysis of Landsat ETM data. ISPR Journal of Photogrammetry and Remote Sensing, v.62, p.309-324, 2007.

ASIS, A.M. de; OMASA, K.; OKI, K.; SHIMIZU, Y. Accuracy and applicability of linear spectral unmixing in delineating potential erosion areas in tropical watersheds. International Journal of Remote Sensing, v.29, p.4151-4171, 2008.

BONANSEA, M.; LEDESMA, C.; RODRÍGUEZ, C.; PINOTTI, L.; HOMEM ANTUNES, M.A. Effects of atmospheric correction of Landsat imagery on lake water clarity assessment. Advances in Space Research, v.56, p.2345-2355, 2015. DOI: 10.1016/j. asr.2015.09.018.

DE JONG, S.M.; PARACCHINI, M.L.; BERTOLO, F.; FOLVING, S.; MEGIER, J.; DE ROO, A.P.J. Regional assessment of soil erosion using the distributed model SEMMED and remotely sensed data. Catena, v.37, p.291-308, 1999.

DURIGON, V.L.; CARVALHO, D.F.; ANTUNES, M.A.H.; OLIVEIRA, P.T.S.; FERNANDES, M.M. NDVI time series for monitoring RUSLE cover management factor in a tropical watershed. International Journal of Remote Sensing, v.35, p.441-453, 2014. DOI: 10.1080/01431161.2013.871081.

GANASRI, B.P.; RAMESH, H. Assessment of soil erosion by RUSLE model using remote sensing and GIS - a case study of Nethravathi Basin. Geoscience Frontiers, v.7, p.953- 961, 2016. DOI: 10.1016/j.gsf.2015.10.007.

GELAGAY, H.S.; MINALE A.S. Soil loss estimation using GIS and remote sensing techniques: a case of Koga watershed, Northwestern Ethiopia. International Soil and Water Conservation Research, v.4, p.126-136, 2016. DOI: 10.1016/j. iswer.2016.01.002.

HAZARIKA, M.K.; HONDA, H. Estimation of soil erosion using remote sensing and GIS, its valuation and economic implications on agricultural production. In: INTERNATIONAL SOIL CONSERVATION ORGANIZATION MEETING, 10., 1999, West Lafayette. Sustaining the global farm: [proceedings]. West Lafayette: International Soil Conservation Organization, 2001. p.1090-1093. Editors: Diane E. Stott, Rabi, H. Mohtar, Gary C. Steinhardt.

HUETE, A.; LIU, H.Q.; BATCHILY, K.; VAN LEEUWEN, W. A comparison of vegetation indices over a global set of TM Images for EOS-MODIS. Remote Sensing of Environment, v.59, p.440-451, 1997. DOI: 10.1016/S0034-4257(96)00112-5.

HUETE, A.R. A soil-adjusted vegetation index (SAVI). Remote Sensing of Environment, v.25, p.295-309, 1988. DOI: 10.1016/0034-4257(88)90106-X.

HYAMS, D.G. CurveExpert software. 2010. Available at: $<$ http://www.curveexpert.net>. Accessed on: Feb 172017.

JIANG, Z.; HUET, A.R.; DIDAN, K.; MIURA, T. Development of a two-band enhanced vegetation index without a blue band. Remote Sensing of Environment, v.112, p.3833-3845, 2008. DOI: 10.1016/j.rse.2008.06.006.

MACHADO, R.L.; CARVALHO, D.F. de; COSTA, J.R.; OLIVEIRA NETO, D.H. de; PINTO, M.F. Análise da erosividade 
das chuvas associada aos padrões de precipitação pluvial na região de Ribeirão das Lajes (RJ). Revista Brasileira de Ciência do Solo, v.32, p.2113-2123, 2008. DOI: 10.1590/S010006832008000500032.

MACHADO, R.L.; RESENDE, A.S. de; CAMPELLO, E.F.C.; OLIVEIRA, J.A.; FRANCO, A.A. Soil and nutrient losses in erosion gullies at different degrees of restoration. Revista Brasileira de Ciência do Solo, v.34, p.945-954, 2010. DOI: 10.1016/j.rse.2008.06.006.

MARTINS, S.G.; SILVA, M.L.N.; CURI, N.; FERREIRA, M.M.; FONSECA, S.; MARQUES, J.J.G.S.M. Perdas de solo e água por erosão hídrica em sistemas florestais na região de Aracruz (ES). Revista Brasileira de Ciência do Solo, v.27, p.395-403, 2003. DOI: 10.1590/S0100-06832003000300001.

MELLO, C.R.; VIOLA, M.R.; BESKOW, S.; NORTON, L.D. Multivariate models for annual rainfall erosivity in Brazil. Geoderma, v.202-203, p.88-102, 2013. DOI: 10.1016/j. geoderma.2013.03.009.

MÜLLER-WILM, U. Sen2Cor 2.2.1 - software release note. [France]: European Space Agency, 2016. 18p.

OLIVEIRA, J.A. Caracterização física da Bacia do Ribeirão Cachimbal-Pinheiral (RJ) e de suas principais paisagens degradadas. 1998. 142p. Dissertação (Mestrado) - Universidade Federal Rural do Rio de Janeiro, Seropédica.

PIRES, L.S.; SILVA, M.L.N.; CURI, N.; LEITE, F.P.; BRITO, L. de F. Erosão hídrica pós-plantio em florestas de eucalipto na região centro-leste de Minas Gerais. Pesquisa Agropecuária Brasileira, v.41, p.687-695. 2006. DOI: 10.1590/S0100-204X2006000400021.

RENARD, K.G.; FOSTER, G.R.; WEESIES, G.A.; MCCOOL, D.K.; YODER, D.C. Predicting soil erosion by water: a guide to conservation planning with the revised universal soil loss equation (RUSLE). Washington: USDA, 1997. 384p. (USDA. Agriculture handbook, n. 703).

ROCHA JUNIOR, P.R. da; ANDRADE, F.V.; MENDONÇA, E. de S.; DONAGEMMA, G.K.; FERNANDES, R.B.A.; BHATTHARAI, R.; KALITA, P.K. Soil, water, and nutrient losses from management alternatives for degraded pasture in Brazilian Atlantic Rainforest biome. Science of the Total Environment, v.583, p.53-63, 2017. DOI: 10.1016/j.scitotenv.2016.12.187.

ROUSE, J.W.; HAAS, R.H.; SCHELL, J.A.; DEERING, D.W.; HARLAN, J.C. Monitoring the vernal advancement of retrogradation (greenwave effect) of natural vegetation. Greenbelt: NASA, 1974. 371p. NASA/GSFC, Type III, Final Report.

SAMUEL-ROSA, A. Análise de fontes de incerteza na modelagem espacial do solo. 2016. 278p. Tese (Doutorado) Universidade Federal Rural do Rio de Janeiro, Seropédica.

SANTOS, H.G. dos; JACOMINE, P.K.T.; ANJOS, L.H.C. dos; OLIVEIRA, V.A. de; LUMBRERAS, J.F.; COELHO, M.R.; ALMEIDA, J.A. de; CUNHA, T.J.F.; OLIVEIRA, J.B. de. Sistema brasileiro de classificação de solos. 3.ed. rev. e ampl. Brasília: Embrapa, 2013. 353p.

SHIMABUKURO, Y.E.; SMITH, J.A. The least-square mixing models to generate fraction imagens derived from remote sensing multispectral data. IEEE Transactions on Geoscience and Remote Sensing, v.29, p.16-20, 1991. DOI: 10.1109/36.103288.

VAEZI, A.R.; HASANZADEH, H.; CERDÀ, A. Developing an erodibility triangle for soil textures in semi-arid regions, NW Iran. Catena, v.142, p.221-232, 2016. DOI: 10.1016/j.catena.2016.03.015.

VAN DER KNIJFF, J.M.; JONES, R.J.A.; MONTANARELLA, L. Soil Erosion Risk Assessment in Italy. Ispra: European Commission Directorate General JRC, Joint Research Centre, Space Applications Institute, European Soil Bureau, 1999. (EUR19022EN).

WANG, L.; DALABAY, N.; LU, P.; WU, F. Effects of tillage practices and slope on runoff and erosion of soil from the Loess Plateau, China, subjected to simulated rainfall. Soil and Tillage Research, v.166, p.147-156, 2017. DOI: 10.1016/j.still.2016.09.007. WORLD reference base for soil resources 2014: international soil classification system for naming soils and creating legends for soil maps: update 2015. Rome: FAO, 2015. (World Soil Resources Reports, 106).

$\overline{\text { Received on February 17, } 2017 \text { and accepted on June 26, } 2017}$

Pesq. agropec. bras., Brasília, v.53, n.3, p.332-341, Mar. 2018 DOI: $10.1590 / \mathrm{S} 0100-204 X 2018000300008$ 